\title{
SOCIAL CAPITAL FOR THE SUSTAINABLE ECONOMY OF BANGLADESH
}

\author{
[Md. Hasan Ali, Mohammad Masud Parves, Umme Saara Khan]
}

\begin{abstract}
Now-a-days knowledge people are familiar with the concept of social capital. The terminology actually comes from the sociology as the part of social science that derives the collective economic benefit. This paper aims to analyze the importance and influence of social capital on the sustainable economy of our country. There are some mechanisms that operate social capital, process of creating social capita. Intervening to strengthen social capital - as a "Self-help groups "is one of the major concerns.
\end{abstract}

Keywords-knowledge people, social capital, sociology, social science, self-help groups.

\section{i. INTRODUCTION}

"Social capital" is the social cohesion and personal investment in the community that creates the value network. The concept is about expected collective or economic benefits derived from the preferential treatment and cooperation between individuals and groups. In the first half of the 19th century, American life that seemed to outline and define social capital but now the concept spreads all over the world and in Bangladesh as well. This concept actually paves the way of development and improves efficiency. "...features of social organization, such as trust, norms [or reciprocity], and networks [of civil engagement], that can improve the efficiency of society by facilitating co-ordinate actions." Putnam, Leonardi and Nanetti (1993). This way and format of economy ensures the quality and quantity of social interaction for the development and growth. "....the institutions, relationships, and norms that shapes the quality and quantity of a society's social interactions." World Bank (2000). In Bangladesh social capital is often linked to the success of democracy and political involvement. This is the concept for whole nation and self interest is also important in this issue. In Bangladesh PPP (Public Private Partnership) is the example that defines the mutual interest of development of Bangladesh. They propose that social capital be defined as the "sympathy". The object of another's sympathy has social capital. One of the main advantages of having social capital is that it provides access to resources on preferential terms.

\section{Md. Hasan Ali}

Assistant Professor, Department of Finance and Banking Faculty of Business Studies

Dhaka Commerce College, Bangladesh

\section{Mohammad Masud Perves}

Assistant Professor, Department of Accounting

Faculty of Business Studies

Dhaka Commerce College, Bangladesh

\section{Umme Saara Khan}

Bachelor Student of Business Administration,

BRAC Business School (BBS)

BRAC University ,Bangladesh

\section{ii. LITERATURE REVIEW}

In the past two or three decades, scholars have taken an interest on social capital in particular. In Bangladesh people view social capital from different perspectives. It is the combination of resources, mutual benefit or some institutional acquisition. The influential French sociologist Pierre Bourdieu (1930-2002) was interested in the ways. He goes on to define social capital as follows: Social capital is the sum of the resources, actual or virtual, that accrue to an individual or a group by virtue of possessing a durable network of more or less institutionalized relationships of mutual acquaintance and recognition. (Bourdieu, in Bourdieu \& Wacquant, 1992: 119). Here in Bangladesh social capital is also the part of individual family and it encompasses that rearing the society as like a child. If the human capital possessed by parents is not complemented by social capital embodied in family relations, it is irrelevant to the child's educational growth that the parent has a great deal, or a small amount, of human capital. (Coleman, 1988: 110). Social capital is used as a source of useful everyday information, and of norms and sanctions of the society in Bangladesh. Social capital also termed for problem solving tools of our society. Social capital has been shown to be valuable for solving collective action problems such as forest management, distribution of irrigation water and reduction of crime in the neighborhood (Woolcock and Narayan, 2000).Being a developing country, Bangladesh is emerging itself as the change maker of the economy. From home to industry it makes the successful steps for sustaining itself in the competitive world economy. The more a country comes forward it means the uses of social capital is more. The more social capital is used, the more it grows (Coleman 1988). In the recessionary period Bangladesh has managed macroeconomics stability and discipline in fiscal front by adopting social capital. By adopting social capital Bangladesh has gain a satisfactory growth path in GDP. In Bangladesh the growth of currency notes and coins with the public has increased after adopting social capital. Social capital has left an evolutionary effect also in the capital market of Bangladesh. The actual focus is on the overall sustainable economy and its growth as the match up with social capital.

\section{iii. OBJECTIVE OF THE STUDY}

Broad objective: To explore the overall sustainable economic growth of Bangladesh with social capital.

Specific Objective: There are some specific objective of the study, these are:

1) To explore the overall economic scenario with social capital.

2)To know the impact of social capital on financial and non-financial institution.

3) To explore how man power is significant in social capital.

4) To define how environmental factors are important in social capital 
Proc. of The Fifth Intl. Conf. On Advances in Applied Science and Environmental Technology - ASET 2016 Copyright ( I Institute of Research Engineers and Doctors, USA .All rights reserved.

ISBN: 978-1-63248-106-1 doi: 10.15224/ 978-1-63248-106-1-43

\section{iv. METHODOLOGY}

For the purpose of the study relevant data has been collected from different sources. All secondary data is collected from the relevant sources that include: different journals, books, articles, directories and internet. Qualitative techniques were used to analyze the collection of data.

\section{v. THE CONCEPTUAL FRAMEWORK OF SOCIAL CAPITAL AND SOCIAL COHERENCE}

In this study, we remark social capital is understood as the stock of available productive resources of the economy, both from potential and realized form that occupy in a stable social network. These resources are held by the group of a society but are available to its individual members. The benefits of membership in a cohesive network extend still by enabling the conversion and exchange of other forms of capital (e.g. economic, political, and cultural). Social cohesion is an important antecedent of social capital; that is, without network cohesiveness, social capital resources are nowhere near as readily mobilized for a particular purpose. (Toomey P, Hanlon N, Bates J, Poole G, Lovato CY: 2010).

Figure 1: Modified version of Carpiano's Bourdieu-based model

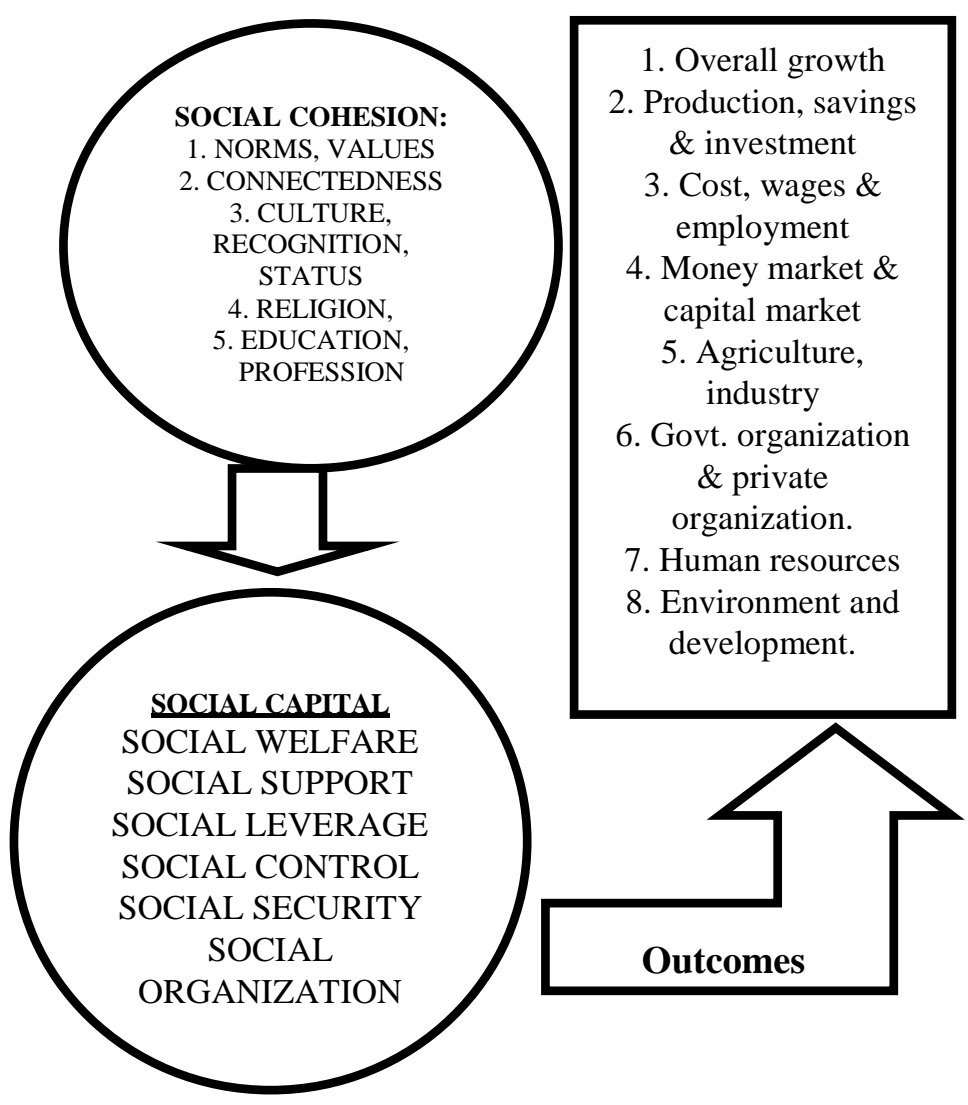

Source: Modified by authors.

\section{vi. MECHANISMS OF SOCIAL CAPITAL OUTCOMES}

Five mechanisms for how social capital affects outcomes

Narayan and Pritchett (1997) describe five mechanisms for how social capital affects outcomes. They are:

a) Improve society's ability to monitor the performance of government, either because government officials are more embedded in the social network or because monitoring the public provision of services is a public good:

b) Increase possibilities for co-operative action in solving problems with a local common property element;

c) Facilitate the diffusion of innovations by increasing inter-linkages among individuals;

d) Reduce information imperfections and expand the range of enforcement mechanisms, thereby increasing transactions in output, credit, land and labor markets;

e) Increase informal insurance (or informal safety nets) between households, thereby allowing households to pursue higher returns, but more risky, activities and production techniques.

\section{viii. ANALYSIS OF THE SOCIAL CAPITAL OF BANGLADESH}

\section{A. MACROECONOMIC SITUATION}

The economy of Bangladesh has successfully tackled the contagion effect of global economic crisis and managed to maintain a sustained growth. According to a provisional estimate, the economy has posted a growth of 6.66 percent in FY2010-11 against that of 6.07 percent in FY2009-10. (Bangladesh economic review: 2011) This performance is mainly attributable to the sustained growth in agriculture sector coupled with recovery of growth in industry sector and the satisfactory performance of service sector. During this period, higher growth in revenue mobilization and prudent budget management helped maintain macroeconomic stability and discipline in fiscal front. Furthermore, the increasing global demand for goods and services after recovery has helped achieving higher growth in foreign trade, while soaring global food and non-food prices has created inflationary pressure in the country. Alongside adopting various administrative and structural measures, monetary policy instruments have also been used to reduce the inflationary pressure. Moreover, slower growth in remittance inflows and higher import demand due to massive investment in infrastructure sector including the power sector, the current account balance and exchange rate was under pressure during the last quarter of FY201011. However, this situation did not emerge as a big challenge to the macroeconomic stability. The foreign exchange reserve remained steady at above US\$ 10 billion during this period. Overseas job replacement and remittance inflows rebounded since January 2011. It is expected that, improved infrastructure and streamlined power sector would be conducive to domestic and foreign 
investment, which will lead the country to the higher growth trajectory.

\section{B. ECONOMIC GROWTH}

The economy had experienced modest fall of GDP growth during the recessionary period. Despite continuous growth in agriculture sector, the sluggish growth in industry sector particularly in the manufacturing sector compared to prerecession period was responsible for slower GDP growth. However, in the wake of global recovery the economy rebounded and has posted a growth of 6.66 in FY2010-11 as compared to 6.07 percent and 5.74 percent growth in FY2009-10 and FY2008-09 respectively. (Bangladesh economic review: 2011) This performance is mainly attributable to the sustained growth in agriculture sector coupled 3 with recovery of growth in industry sector and the satisfactory performance of service sector. Agriculture recorded sustained growth for the last three consecutive fiscal years responding to favorable weather conditions, continued government support for agriculture inputs and greater access to credit. Industry sector rebounded from the sluggish growth during recession and recorded a robust growth of 8.16 percent, up from 6.49 percent of previous year. Massive initiatives taken by the government in the overall infrastructure sectors including the power helped to improve industrial production. Service sector has maintained satisfactory growth path and recorded 6.63 percent growth, slightly higher than the growth of previous year $(6.47$ percent). In FY2010-11, per capita GNI and per capita GDP stood at US\$ 818 and US\$ 755 respectively, up from US\$ 751 and US\$ 687 respectively a year earlier.(www.mof.gov.bd)

\section{SOCIETITIES SAVINGS AND INVESTMENT}

According to a provisional estimate, domestic savings decelerated from 20.10 percent of GDP in FY2009-10 to 19.59 percent of GDP in FY2010-11 mainly for increasing consumption expenditure. While due to slower growth in remittance inflow, national savings decelerated from 30.02 percent of GDP in FY2009-10 to 28.40 percent of GDP in FY2010-11. Moreover, due to higher investment in Annual Development Program, investment-GDP ratio stood at 24.73 percent of GDP in FY2010-11, up from 24.41 percent of GDP a year earlier.

\section{MONEY AND CREDIT}

The broad money increased by 21.34 percent during FY2010-11, which was slightly lower than 22.44 percent growth a year earlier. During this period, year-on-year growth of currency notes and coins with the public increased by 18.71 percent compared to the increase of 28.04 percent a year earlier. While demand deposit increased by 15.48 percent from 37.70 percent and the time deposit recorded an increase by 22.68 percent from 19.55 percent a year earlier.

\section{E. CAPITAL MARKET}

The capital markets became volatile from the second half of FY2010-11. During the period, the DSE general index increased by 98.43 percent from $3,010.26$ to $6,153.68$ indicating keen interests showed by the investors in the capital market. By the end of June 2010, the number of BO (Beneficiary Owner) accounts has increased to 25.64 lakh from 14.15 lakh at the end of June 2009. At the beginning of FY2010-11, the capital market showed buoyant. The DSE general index stood at $8,290.41$ in December 2010, up by
34.72 percent compared to that of June 2010. Similarly, market capitalization stood at 44.1 percent of GDP at that time. However, the overheated capital markets collapsed in January 2011 and were in process of recovery and stabilization during the last quarter of FY2010-11. Market capitalization and general index of DSE stood at 36.24 percent of GDP and 5,093.19 at the end of FY2010-11.

\section{F. EXTERNAL SECTORS}

\section{a) Export}

With the recovery of global economy from recession, Bangladesh's export trade has been performing better. Export recorded a robust growth of 41.47 percent in FY2010-11, as against 4.11 percent during the previous fiscal year. Such growth was contributed mainly by the growth of export of raw jute (82.14 percent), knitwear (46.26 percent), agriculture products (42.39 percent), frozen food (40.45 percent), jute goods (40.37 percent), woven garments (40.23 percent) and leather (31.86 percent).

\section{b) Import}

In FY2010-11, imports picked up and grew by 41.79 percent, as against 5.53 percent during the previous fiscal year as the global economy started to recover and international commodity price increased. In addition, higherthan-expected import of food grains, imports of machinery for newly established power plants and demand for petroleum for running the plants contributed to the sharp rise in import. Based on the settlement of Letters of Credit (LCs) in FY2010-11, import payments of food grains stood a record high at US \$1993.60 million during FY2010-11, up by 133.3 percent as compared to US $\$ 854.51$ million in the previous year. The import of industrial raw materials increased by 46.63 percent, while that of capital machinery and machinery for miscellaneous industries increased by 40.21 percent and 36.19 percent respectively during the period. The import of petroleum and petroleum products rose by 38.73 percent during the period.

\section{c) Expatriate Employment and Remittances}

The slowdown in the growth of remittance reflected the impact of global recession, particularly on the real estate markets in the Middle East, and on industrial labor demand in some South East Asian economies such as Malaysia. Despite the recovery, the recent political turmoil in North Africa and Middle East negatively affect the expatriate employment. However, the overseas employment rebounded since January, 2011. The number of overseas workers during FY2010-11 was 4.39 lakh, up marginally by 2.8 percent compared to that of the previous year. Against this backdrop, the Government has been taken several initiatives to further improve the situation. Moreover, there are potential demands for Bangladeshi workforces in Eastern Europe, South Africa and North American Countries. The Government is also trying to encourage more workers to go to these destinations. In tandem with these, National Skill Development Council would be strengthened to develop skilled labor force to sustain overseas labor market.

\section{d) Foreign Exchange Reserve}

Due to decline in current account surplus and the deficit in the capital and financial accounts, there was a deficit in the overall balance. The gross official foreign exchange reserves was almost pleatued over the period and stood at US\$ 
Proc. of The Fifth Intl. Conf. On Advances in Applied Science and Environmental Technology - ASET 2016 Copyright ( I Institute of Research Engineers and Doctors, USA .All rights reserved.

ISBN: 978-1-63248-106-1 doi: 10.15224/ 978-1-63248-106-1-43

10,912.00 million as on June 30, 2011, which was 1.51 percent higher than the amount as on June 30, 2010. As on June 30, 2011, the reserve was equivalent to the import payments for about 3.89 months.

\section{ix. CREATION OF SOCIAL CAPITAL BY MICRO-FINANCE}

As mentioned earlier there is a huge literature on social capital. Despite the success of Microfinance, with a few exceptions, the literature has ignored the social capital building aspects of Microfinance. In our country Grameen Bank is the pioneer in micro-finance. It works for the rural people of our country. Social business as the new format of business emerges radically all over the world moves to the capitalizing. Grameen Bank started as an action research project by Muhammad Yunus, a Bangladeshi economist in Chittagong in 1976. The objective of the project was to test whether the poor are credit worthy and if credit can be supplied without any collateral. Later with the help from some Nationalized Commercial Banks, Professor Yunus was able to provide a formal structure to his experiment essentially serving as an intermediary lender, by lending bank funds to the rural landless, collecting repayments and depositing them with the NCBs. Soon the bank became a project of the central bank and it supported this work by facilitating funding from the International Fund for Agricultural Development (IFAD). After 7 years of experimentation, in 1983, Grameen Bank was established as a specialized bank with its own charter to work exclusively with the poor, defined as individuals owning less than half an acre of land. (Dowla, A., 2000)

\section{x. INTERVENING TO STRENGTHEN SOCIAL CAPITAL - Self-help groups}

What types of intervention have been used most successfully to promote participation in social capital? Social capital concept helps to create collective groups that helps individual for mutual benefit. A self-help people works for social coherence and a common goal is the actual target. A synthesis by Oakley et al (1991) proposes the following six dimensions.

\begin{tabular}{|l|l|}
\hline Animation & $\begin{array}{l}\text { Assisting local people stimulate their } \\
\text { own critical awareness, to examine and } \\
\text { explain issues in their own words, and } \\
\text { to realize what they can do to bring } \\
\text { about change. }\end{array}$ \\
\hline Structuring & $\begin{array}{l}\text { The development of internal cohesion } \\
\text { and solidarity among people, and some } \\
\text { form of structured organization }\end{array}$ \\
\hline Facilitation & $\begin{array}{l}\text { A service role which assists people to } \\
\text { undertake specific actions; these } \\
\text { actions include the acquiring of } \\
\text { particular technical and managerial } \\
\text { skills, gaining access to available } \\
\text { resources or translating their own ideas } \\
\text { into feasible projects. }\end{array}$ \\
\hline Intermediary & $\begin{array}{l}\text { To serve as a go-between in relation to } \\
\text { other external services. }\end{array}$ \\
\hline Linking & $\begin{array}{l}\text { To help develop links between people } \\
\text { in similar contexts and facing similar } \\
\text { problems. }\end{array}$ \\
\hline Withdrawal & $\begin{array}{l}\text { A progressive redundancy of external } \\
\text { intervention. }\end{array}$ \\
\hline
\end{tabular}

\section{xi. CONCLUSION}

This paper adopts a holistic approach to explain why social capital matters for effective implementation, widespread uptake, greater social inclusion; It describes a theoretical framework drawn from diffusion of innovation, community development and social capital theories in different perspective.

\section{References}

[1] Bourdieu, Pierre, and Wacquant, Loic J. D. (1992), An Invitation to Reflexive Sociology, Chicago: University of Chicago Press.

[2] Coleman, James S. (1988), 'Social Capital in the Creation of Human Capital', American Journal of Sociology, Vol. 94, Supplement: Organizations and Institutions: Sociological and Economic Approaches to the Analysis of Social Structure, pp. S95-S120.

[3] Coleman, James S.: Social capital in the creation of human capital. American Journal of Sociology, vol. 94 (1988) Supplement, 95-120. contemporary American discourse of civil society. In: Mark E. Warren (ed.): Democracy and Trust. Cambridge: Cambridge University Press 1999, 208-248.

[4] Carpiano RM. Toward a neighborhood resource-based theory of social capital for health: can Bourdieu and sociology help? Social Science and Medicine 2006; 62: 165-175.

[5] Dowla, A., 2000. "Grameen Bank and Women's Empowerment in Bangladesh: A Review Essay" Department of Economics. (The Journal of SocioEconomics 35 (2006) 102-122 )St. Mary's College of Maryland, mimeograph.

[6] Narayan and Pritchett (1997) Cents and Sociability: Household Income and Social Capital in Rural Tanzania, World Bank, Washington DC, USA

[7] Nicole J. Schaefer-McDaniel ,(2003) Conceptualizing Social Capital among Young. People: Towards a New Theory.

[8] Oakley et al (1991), Projects with People: The Practice of Participation in Rural Development, International Labour Organisation, Geneva, Switzerland

[9] Putnam, Leonardi and Nanetti (1993) Making Democracy Work: Civic Traditions in Modern Italy, Princeton University Press, Princeton, USA.

[10] Toomey P, Hanlon N, Bates J, Poole G, Lovato CY. Exploring the role of social capital in supporting a regional medical education campus. Rural and Remote Health11: 1774. (Online) 2011. Available: http://www.rrh.org.au

[11] Woolcock, M., Narayan, D., 2000. Social capital: implications for development theory, research, and policy.World Bank Research Observer 15 (2), 225-249.

[12] http://www.mof.gov.bd

[13] World Bank (2000) What is Social Capital? From www.worldbank.org/poverty 
Proc. of The Fifth Intl. Conf. On Advances in Applied Science and Environmental Technology - ASET 2016 Copyright (C) Institute of Research Engineers and Doctors, USA .All rights reserved.

ISBN: 978-1-63248-106-1 doi: 10.15224/ 978-1-63248-106-1-43

\section{Authors}

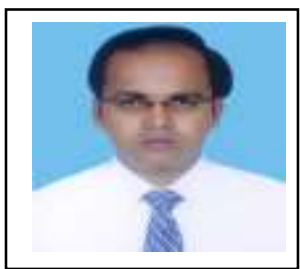

Md. Hasan Ali has been serving as an Assistant Professor of the Department of Finance and Banking in Dhaka Commerce College, Mirpur ,Dhaka, Bangladesh. He is a graduate of National University. Also, he is an M.Phil Researcher at BUP.

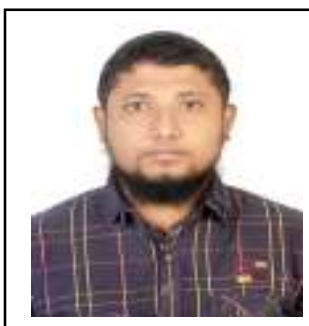

Mohammad Masud Perves has been serving as an Assistant Professor of the Department of Accounting in Dhaka Commerce College, Mirpur ,Dhaka, Bangladesh. He is a graduate of National University. He has numerous publications in different national and international journals.

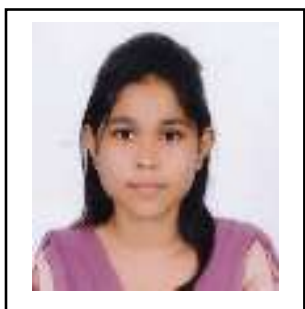

Umme Saara Khan, studying Bachelors of Business Administration at BRAC Business School in BRAC University, Bangladesh. She is working as a research assistant. She likes to write articles in different national and international papers. 